\title{
The relationship between innovation, knowledge, and performance in family and non-family firms: an analysis of SMEs
}

\author{
David P Price*, Michael Stoica and Robert J Boncella
}

\author{
* Correspondence: \\ david.price@washburn.edu \\ Washburn University, 1700 SW \\ College Ave, Topeka, KS 66621, USA
}

\begin{abstract}
This study seeks to examine the relationship between innovation and knowledge in family versus non-family businesses with regard to performance. Data from 430 small and medium-sized enterprises were analyzed through hierarchical regression analysis, and innovation was found to be a significant factor in both family and non-family samples. However, knowledge in family firms was also found to be significant with innovation. Implications for theory and practice are discussed that may provide possible competitive advantage for small family firms.
\end{abstract}

Keywords: Family firms; Innovation; Knowledge resources; SMEs

\section{Background}

Increasingly, innovation in new products/services and the implementation of key processes are becoming vital sources for firm competitive advantage (Rumelt 1984; Liao et al. 2009). For example, research suggests that firms that engage in developing innovative products and services are positioned to compete more successfully through the development of new products and processes, before competitors in first-mover advantage, increasing market share, return on investment (ROI), and overall firm success (Allocca and Kessler 2006; Gudmunson et al. 2003).

Similarly, family firms have dominated small and medium-sized enterprise (SME) creation in many countries (Astrachan and Shanker 2003; Chrisman et al. 2005). Understanding how family SMEs achieve high performance in order to impact society has significant implications for family owners and managers, the SME employees, and the economies in which the family SME operates. High levels of performance can facilitate firm growth and subsequent profit performance, which in turn can yield employment gains and contribute to the general economic health of a state, region, or nation (Wolff and Pett 2006).

Literature on SMEs and family business operations overlap in several ways. For example, family-owned businesses often lack infrastructure capabilities such as technology or appropriate management techniques that can lead to inferior performance, and many of the resource constraints faced by SMEs are found in family firms (Astrachan et al. 2003; Eddleston et al. 2008; Klein 2000). The purpose of this research is to examine innovation and knowledge and how these variables may influence the performance

(C) 2013 Price et al.; licensee Springer. This is an Open Access article distributed under the terms of the Creative Commons Attribution License (http://creativecommons.org/licenses/by/2.0), which permits unrestricted use, distribution, and reproduction in any medium, provided the original work is properly cited. 
of SMEs in family firms. It is hoped that this research provides a framework for analyzing the competitive advantage currently found in the family business literature.

\section{Family business}

The field of family business research has been gaining impetus in recent years (Chrisman et al. 2010; De Massis et al. 2012; Kellermanns et al. 2010; Sharma et al. 2012). However, there appears to be less family research on SMEs, which is surprising as many have indicated that a large number of new firms are founded by two or more individuals who are related (Reynolds and White 1997; Ruef et al. 2002). There appears to be a lack of uniformity when discussing the field of family business as a paradigm in research and practice (Sharma 2004). While scholars from many disciplines have conducted research on family firms that adds to the breadth of diversity in the field, it has lacked a cohesive structure. Recent research on family firms has led us to understand that certain characteristics of family firms, such as the differences in family involvement and the long-term orientation of family members, may affect many different aspects of the firm (Chrisman et al. 2010; Gedajlovic and Carney 2010; Ling and Kellermanns 2009; Le Breton-Miller and Miller 2006; Peng and Jiang 2010).

Numerous attempts have been made to express a definition for family firms (Sharma 2004). Most often these attempts have been to delineate family from non-family firms. This line of thought suggests that family firms create a unique vision and control mechanisms that benefit the firm through the creation of distinctive resources and capabilities (Chrisman et al. 2005; Kellermanns et al. 2010; Zellweger and Nason 2008).

Family businesses may have several distinctive qualities that differentiate them from non-family firms. Firstly, family firms have been known to maintain a defensive posture that suggests a lack of growth or proactive orientation (Martin and Lumpkin 2003) which has been suggested to lead to higher performance (Short et al. 2009). Secondly, these conservative positions suggest that they have a tendency towards a long-term orientation that avoids risk-taking (Dess et al. 2011). This tendency leads to a third quality for a focus on survival, which suggests quick response and tight management control within the family structure (Hambrick and D'Aveni 1988). These differences have led to distinctive decisionmaking qualities to differentiate the family firm (Smith and Lewis 2011).

Family firms differ in the amount of family involvement (Astrachan and Shanker 2003; Lumpkin et al. 2010). Family business definitions include family ownership, management by a family member, operational involvement of a family member, and involvement across generations (Heck and Trent 1999). Research has evolved from this overemphasis on the firm and family system while still maintaining that there indeed exists a difference between the two (Steir 2009). However, as stated by Sharma (2004) in a meta-analysis of the field, there is 'no distinct set of variables separating family and non-family firms' (p. 5). This research attempts to examine relationships in family and non-family firms by investigating two important intangible resources: innovation and knowledge, that may lead to competitive advantage in family firms.

\section{Innovation}

Research on innovation in firms is important as there may be a unique set of processes and resources involved that may help explain innovation as a critical factor in 
predicting SME performance (Anderson and Eshima 2011; Achtenhagen et al. 2010). Innovation has been discussed as the development of a new product, the process of developing a new product, or the adoption of a new product, which also can be investigated at various levels, such as the project level, industry sector, or region (Christenson 1997). It has been described as 'the successful implementation of creative ideas' (Amabile 1996, p. 1), which can lead to solutions to problems that can have a potential impact on revenues of a firm, industry sector effectiveness, and the prosperity of nations (Porter 1996; Harrison and Huntington 2000). The U.S. Small Business Administration (SBA) defines innovation as 'a process that begins with an invention, proceeds with the development of the invention, and results in the introduction of a new product, process or service to the marketplace.' Even more simply, Glynn (1996) described the process as two main phases: invention (initiation of the idea) and implementation.

Innovation is important for small firms as large companies recognize the ability of smaller firms to capture innovation, will often tap the creativity of small growthoriented firms to remain competitive, and have acknowledged that fostering innovation is very effective via linking to smaller entrepreneurial firms. Family firm innovation in larger firms has been investigated from the viewpoint of single versus multiple ownership, finding single owners to be more innovative and showing greater entrepreneurial orientation (Miller et al. 2011) and spending more on innovative factors, such as R\&D and increased productivity (Block 2012).

Innovation in firms has been studied in several forms in the entrepreneurship literature. For example, a firm's 'entrepreneurial orientation' suggests that a combination of three basic dimensions: innovativeness, proactiveness, and risk-taking, creates the factors closely tied to an entrepreneurial firm (Covin and Slevin 1989; Moreno and Casillas 2008; Wiklund and Shepherd 2005). Innovativeness reflects a tendency to support new ideas, novelty, experimentation, and creative processes, thereby departing from established practices and technologies (Lumpkin and Dess 1996). The importance of a small firms' innovation strategy is demonstrated in a prominent study of by Bruderl and Preisendorfer (2000), who discovered that innovation is the single most important factor in predicting firm growth.

For family firms, it has been suggested that they are not as innovative and more prone to be risk-averse than non-family firms, due to capital constraints and the closeness of the family (Allio 2004; Carney 2005). Research suggests that limited resources and capabilities in smaller family firms inhibit their ability to innovate, although other means of innovation are achieved through off-the-cuff concepts and technologies and other resources offered through networks Verhees and Muelenberg Verhees and Muelenberg (2004).

However, recent research has disputed these findings and acknowledged that family firms act boldly and exhibit innovative and entrepreneurial tendencies (Naldi et al. 2007; Zahra 2005). Compared to larger firms, there is general acceptance that smaller firms tend to be more flexible and non-bureaucratic and can adopt innovations more quickly (Nooteboom 1994). Thus, new inputs are very important for innovation in small firms, and small and young firms can differentiate themselves by introducing product, process, or market innovations (McGrath 2001).

A critical factor of family firms is the long-term relationship family members have with the firm. Due to this ownership structure, it has been argued that family firms 
have a longer planning cycle that non-family firms, and thus, innovative capacity is increased as innovation usually needs time to develop (Kellermanns et al. 2008). A study by Eddleston and Kellermanns (2007) found that family firm performance improved when owner-managers involved other family members in the business. Involvement in management by family members can increase innovative behavior as family members are more apt to understand challenges and opportunities that face the firm (Zahra 2005).

Spriggs et al. (2012) found an overall link between a family firms' innovativeness and performance in small firms, and other research have suggested that family firms that do devote resources to innovation tend to have greater tendencies toward increased firm performance and growth (Eddleston et al. 2008; Gudmunson et al. 2003; McCann et al. 2001). Thus, innovation may provide an important resource that contributes to firm success (Zahra et al. 2004).

For this study, innovation is defined as the ability to create new value propositions through offering new products and services; adopting new operating practices: technological, organizational, or market-oriented; or creating new skills and competencies (Schumpeter 1947). Thus, firm innovative ability is both focused on content and processes. Given our interpretation of firm innovation, the framework for our hypothesis development is based on new products/services, opportunity recognition, process/practice development, and creativity in accomplishing goals.

Hypothesis 1: There is a positive relationship between innovation and performance in family firms as compared to non-family firms.

\section{Knowledge}

The importance of knowledge-based resources has been well documented in the literature (Cohen and Levinthal 1990; Lee and Sukoco 2007; Wiklund and Shepherd 2003). Knowledge management is understood to have the ability to increase competitive advantage in firms, such as lowering overall costs and developing and increasing employees (Skyrme and Arnindon 1997). Knowledge has been described as contextspecific, as the context of the knowledge management process can affect who and how actors participate (Nonaka et al. 2000), and this contextual connection can be relevant to family-owned enterprises (Nordqvist 2012). Knowledge-based resources have been noted as important for a firm's innovative capacity which aids in the discovery and exploitation of opportunities (Kaya and Patton 2011).

Knowledge in a firm has been broadly classified as firm-specific or general (Helfat 1994; Pavitt 1991). If the knowledge is close to the existing firm knowledge base and with specific applications, this can be firm-specific. The other view of general knowledge is that this form of knowledge exists in the marketplace and is less specialized. Kirzner (1979) distinguished between entrepreneurial knowledge and the knowledge expert, suggesting that it is the entrepreneur of the firm that hires the latter. The knowledge expert does not fully recognize the value of their knowledge or how to turn that knowledge into profit or else the expert would be acting as an entrepreneur. In turn, the entrepreneur may not have the depth of knowledge that the specialist possesses (for example, in technology), but it is the entrepreneur who recognizes the value of the opportunity through the application of the specialist's knowledge. Therefore, as small family firms expand and acquire more knowledge experts, they have the potential to 
lose their 'familiness' as the advantages of knowledge may be changed in its application or reduced.

There lies an intersection of the resource-based view of the firm, the knowledgebased view of the firm, and family firm research. The resource-based view suggests that competitive advantage can be obtained from unique bundles of tangible and intangible assets that are rare, valuable, inimitable, and sustainable (Barney 1991). Knowledgebased resources have been described as one of the most important resources as knowledge can affect the manipulation and transformation of other resources in order to add value to a firm (Teece et al. 1997). The resource-based view has been one of the dominant theories used to explain strategy in family businesses (Chrisman et al. 2005), and family characteristics can affect firm strategy choice (Miller et al. 2011).

Resources can consist of human, social, physical, and organizational resources, among others. Knowledge-based resources suggest that a firm's ability to create and utilize knowledge is one of the most important sources of sustainable competitive advantage (Grant 1996; Wang et al. 2009). It has been suggested that knowledge has the greatest ability of all resources to serve as a source of sustainable differentiation due to immobility (McEvily and Chakravarthy 2002) and general applicability (Miller and Shamsie 1996). Knowledge permits firms to more accurately predict the nature and commercial potential of changes in the environment and the appropriateness of strategic and tactical actions (Cohen and Levinthal 1990). That is, without knowledge, an organization is less capable of discovering and exploiting new and emerging opportunities.

There appears to be a relationship between knowledge and innovation, with research suggesting that knowledge flows are important in the innovation process (Rigby and Zook 2002). Radical innovation research has suggested that a firm's knowledge base represents the most unique resources for radical innovation (Miller et al. 2007; Zhou and $\mathrm{Wu}$ 2010). However, while a knowledge base may give rise to new innovation, without synthesis and utilization efforts, radical innovation is likely to be only incremental (Katz and Du Preez 2008; Laursen and Salter 2006).

Cohen and Levinthal (1990) described the exposure to knowledge as insufficient, that firms must instead recognize and create knowledge, and integrate and utilize the knowledge in the firm. This continuous process is used to identify and exploit existing and acquired knowledge as well as develop new opportunities. Alavi and Leidner (2001) described this process as creating, storing/retrieving, transferring, and applying knowledge. According to Wiklund and Shepherd (2003), the management of knowledge is required to integrate all knowledge in order to anticipate current and future needs. As a simple distinction between family and non-family may be insufficient to capture the effects of performance (Sirmon et al. 2008), this research attempts to position knowledge from a macroperspective and posits that it has a positive relationship with innovation and firm performance:

Hypothesis 2: There is a positive relationship between knowledge, innovation, and performance in family firms as compared to non-family firms.

\section{Family firms and performance}

Evidence of family business performance as opposed to non-family has generally concluded that family firms possess innovative capabilities and thus competitive advantage 
(Andres 2008; McConaugby et al. 2001). There appears to exist several caveats to this statement, such as the measurement of performance (Holt et al. 2010), advantages gained (Burkart et al. 2003), and long-term outlook (Anderson and Reeb 2003). These differences might be partly explained that family involvement affects activities and processes differently, and in turn impact firm performance (Miller and Le Breton-Miller 2006). Performance is critical for family firms as their growth and survival are essential to be passed on to future generations (Kellermanns et al. 2008). Thus, innovative capabilities in family firms are critical for long-term sustainability and competitiveness (Greenwood and Miller 2010).

While the measurement of family performance has been reasonably established, what constitutes a 'family business' is not as easily found. Chrisman et al. (2005) offered an analysis of the relationship between family and performance and suggested at that time that the results in the literature were inconclusive. Kellermanns et al. (2010) also suggested that family firms can have both a positive and negative influence on firm performance. In a meta-analysis by O'Boyle et al. (2012), they found that family firms may indeed have a disadvantage when compared to family firms. As there still seems to remain some levels of disagreement about the performance of family versus non-family firms, this study seeks to understand how intangible variables, which can be unique to family firms, might affect their performance. This model is depicted in Figure 1.

\section{Results}

\section{Descriptive industry statistics}

A total of 430 useable questionnaires were available for analysis; 293 respondents (68\%) were family firms and 137 (32\%) were non-family firms. The most commonly reported industry groupings were similar across the two countries: the retail sector for family (112 businesses or $38.2 \%$ ) and for non-family (46 businesses or 33.6\%). The retail sector was the largest segment overall for both family and non-family. These results are shown in Table 1.

\section{Firm size}

The definition for an SME was discussed based on definitions regarding employment; for Australia, this is less than 100 employees. As the USA defines an SME as a firm that has less than 500 employees, this definition was used as a guiding principle and all respondents could be included in the sample. The results are shown to indicate the total number of employees in 2007, the last full year prior to the survey being administered.

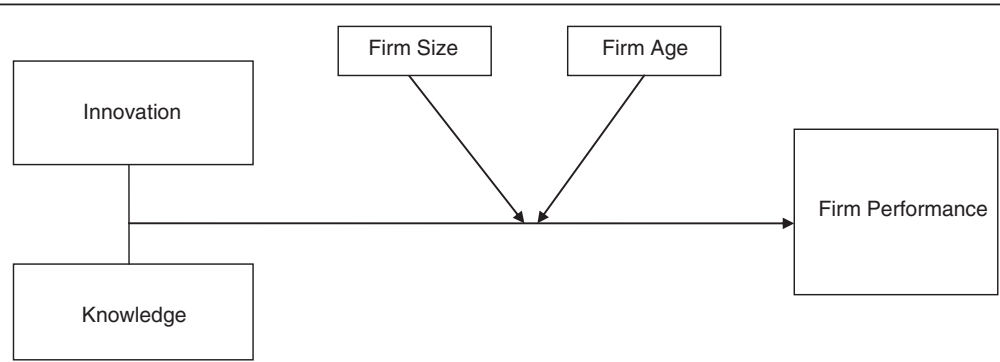

Figure 1 The relationship between a family firm's innovation, knowledge, and firm performance. 
Table 1 Firm characteristics - industry type

\begin{tabular}{|c|c|c|c|c|c|}
\hline \multirow{3}{*}{ Type of business } & \multirow[t]{3}{*}{ Primary NAIC code } & \multicolumn{4}{|c|}{ Businesses participating in the study } \\
\hline & & \multicolumn{2}{|c|}{ Family } & \multicolumn{2}{|c|}{ Non-family } \\
\hline & & Number & $\%$ & Number & $\%$ \\
\hline Agriculture & 1 & 12 & 4.1 & 1 & 0.7 \\
\hline Construction & 2 & 20 & 6.8 & 15 & 10.9 \\
\hline Manufacturing & 3 & 28 & 9.6 & 12 & 8.8 \\
\hline Wholesale & 4 & 14 & 4.8 & 3 & 2.2 \\
\hline Retail & 5 & 112 & 38.2 & 46 & 33.6 \\
\hline Transportation & 6 & 1 & 0.3 & 1 & 0.7 \\
\hline Information & 7 & 14 & 4.8 & 7 & 5.1 \\
\hline Finance and insurance & 8 & 14 & 4.8 & 11 & 8.0 \\
\hline Real estate & 9 & 7 & 2.4 & 6 & 4.4 \\
\hline Professional and technical & 10 & 31 & 10.6 & 16 & 11.7 \\
\hline Health and social & 11 & 3 & 1.0 & 5 & 3.6 \\
\hline Arts and entertainment & 12 & 7 & 2.4 & 5 & 3.6 \\
\hline Accommodation and food & 13 & 26 & 8.9 & 5 & 3.6 \\
\hline Other services & 14 & 4 & 1.4 & 4 & 2.9 \\
\hline Total & & 293 & 100.00 & 137 & 100.00 \\
\hline
\end{tabular}

Family firms included $15.6 \%$ of respondents with 0 employees, and most firms in the family sample had between 1 and 10 employees (68.3\%) as compared to the 10 to 20 category (11.6\%). Only $2 \%$ of firms had over 50 employees. For non-family, $40.8 \%$ of firms had employees in the 1 to 10 category and $34.3 \%$ in the 10 to 20 group. These results are shown in Table 2 .

\section{Firm age}

The findings regarding firm age between the two samples largely mirrored each other. Family firms aged between 1 and 3 years totaled 19.8\% and 17.5\% for non-family. Similarly, those firms aged over 15 years in family totaled $20.1 \%$ and $17.5 \%$ for non-family, respectively. Overall the two samples were very similar. The results are shown in Table 3.

\section{Multiple linear regression analysis}

The model was analyzed with hierarchical linear regression with innovation (INN) and knowledge (KNOW) as the independent variables and performance (PERF) as the

Table 2 Firm characteristics - size (number of employees)

\begin{tabular}{|c|c|c|c|}
\hline Characteristic & Range & $\begin{array}{c}\text { Family businesses } \\
\text { \% } \\
(n=293)\end{array}$ & $\begin{array}{c}\text { Non-family businesses } \\
\% \\
(n=137)\end{array}$ \\
\hline \multirow[t]{5}{*}{ Number of employees } & 0 & 46 & 4 \\
\hline & From 1 to 10 & 200 & 56 \\
\hline & From 10 to 20 & 34 & 47 \\
\hline & From 21 to 50 & 7 & 20 \\
\hline & More than 50 & 6 & 10 \\
\hline
\end{tabular}


Table 3 Firm characteristics - age (in years)

\begin{tabular}{|c|c|c|c|}
\hline Characteristic & Range & $\begin{array}{c}\text { Family businesses } \\
\qquad \begin{array}{c}\% \\
(n=293)\end{array}\end{array}$ & $\begin{array}{c}\text { Non-family businesses } \\
\% \\
(n=137)\end{array}$ \\
\hline \multirow[t]{6}{*}{ Number of years in business } & From 1 to 3 & 58 & 24 \\
\hline & From 4 to 6 & 74 & 51 \\
\hline & From 7 to 9 & 46 & 14 \\
\hline & From 10 to 14 & 56 & 24 \\
\hline & From 15 to 19 & 33 & 10 \\
\hline & 20 and above & 26 & 14 \\
\hline
\end{tabular}

dependent variable. Other variables in the model included control variables: age (AGE) in years and size (SIZE) as number of employees. The results are shown in Tables 4 and 5 .

\section{Hierarchical regression results - family firms}

Model 1 in the family sample was regressed on one control variable, AGE, against PERF. Model 2 includes the two control variables (AGE and SIZE), and no significance is shown. Model 3 examines AGE, SIZE, and KNOW as the first independent variables with strong results for the knowledge variable. Model 3 indicates the adjusted $R^{2}$ is 0.31 , with the model explaining $31 \%$ of the variance. Analysis of variance (ANOVA) $F$ is very significant (43.56) at the $1 \%$ level. Thus, the independent variable knowledge is making a major contribution in the explanation of performance. Knowledge resources have a strong result $(\beta=0.53, t=10.88, p<.01)$. The $t$ value is large at 10.88 and significant at the $1 \%$ level. Interestingly, the control variable AGE becomes significant in Model 3 at the $1 \%$ level $(\beta=-0.16, t=3.25, p<.01)$.

Model 4 is the final optimal model and analyzes the introduction of INN: ( $\beta=0.44, t=$ $7.28, p<.01)$. The adjusted $R^{2}$ improves to 0.41 , with a concomitant jump in the $F$ value (from 43.56 to 51.89 ), and is significant at the $1 \%$ level. Compared to Model 3, the beta coefficients of the two variables remain at a similar level, but there are significant $t$ values for both variables, which fell slightly for knowledge (from 10.88 to 4.02 ) but remained

Table 4 Hierarchical regression - family firms (dependent variable: performance)

\begin{tabular}{|c|c|c|c|c|c|c|c|c|}
\hline \multirow[t]{2}{*}{ Variables } & \multicolumn{2}{|c|}{ Model 1} & \multicolumn{2}{|c|}{ Model 2} & \multicolumn{2}{|c|}{ Model 3} & \multicolumn{2}{|c|}{ Model 4} \\
\hline & $\beta$ & $t$ & $\beta$ & $t$ & $\beta$ & $t$ & $\beta$ & $t$ \\
\hline \multicolumn{9}{|c|}{ Control variables } \\
\hline Age & -0.15 & -2.60 & -0.17 & -2.87 & -0.16 & $3.25^{* * *}$ & -0.12 & $-2.55^{* *}$ \\
\hline Size & & & 0.08 & 1.41 & 0.08 & 1.60 & 0.08 & 1.64 \\
\hline \multicolumn{9}{|c|}{ Independent variables } \\
\hline Knowledge & & & & & 0.53 & $10.88^{* * *}$ & 0.24 & $4.02^{* * *}$ \\
\hline Innovation & & & & & & & 0.44 & $7.28^{* * *}$ \\
\hline Adjusted $R^{2}$ & \multicolumn{2}{|c|}{0.02} & \multicolumn{2}{|c|}{0.02} & \multicolumn{2}{|c|}{0.31} & \multicolumn{2}{|c|}{0.41} \\
\hline$F$ value & \multicolumn{2}{|c|}{6.80} & \multicolumn{2}{|c|}{4.40} & \multicolumn{2}{|c|}{$43.56^{* * *}$} & \multicolumn{2}{|c|}{$51.89^{* * * *}$} \\
\hline Delta $R^{2}$ & & & \multicolumn{2}{|c|}{0.0} & \multicolumn{2}{|c|}{0.29} & \multicolumn{2}{|c|}{0.11} \\
\hline
\end{tabular}


Table 5 Hierarchical regression - non-family firms (dependent variable: performance)

\begin{tabular}{|c|c|c|c|c|c|c|c|c|}
\hline \multirow[t]{2}{*}{ Variables } & \multicolumn{2}{|c|}{ Model 1} & \multicolumn{2}{|c|}{ Model 2} & \multicolumn{2}{|c|}{ Model 3} & \multicolumn{2}{|c|}{ Model 4} \\
\hline & $\beta$ & $t$ & $\beta$ & $t$ & $\beta$ & $t$ & $\beta$ & $t$ \\
\hline \multicolumn{9}{|c|}{ Control variables } \\
\hline Age & 0.13 & 1.55 & 0.14 & 1.59 & 0.05 & 0.63 & 0.05 & 0.58 \\
\hline Size & & & -0.03 & -0.38 & 0.02 & 0.18 & 0.00 & 0.05 \\
\hline \multicolumn{9}{|c|}{ Independent variables } \\
\hline Knowledge & & & & & 0.41 & $5.14 * * *$ & 0.11 & 0.88 \\
\hline Innovation & & & & & & & 0.40 & $3.35^{* * *}$ \\
\hline Adjusted $R^{2}$ & \multicolumn{2}{|c|}{0.01} & \multicolumn{2}{|c|}{0.00} & \multicolumn{2}{|c|}{0.16} & \multicolumn{2}{|c|}{0.22} \\
\hline$F$ value & \multicolumn{2}{|c|}{2.41} & \multicolumn{2}{|c|}{1.27} & \multicolumn{2}{|c|}{$9.80^{* * *}$} & \multicolumn{2}{|c|}{$10.72^{* * *}$} \\
\hline Delta $R^{2}$ & & & \multicolumn{2}{|c|}{0.00} & \multicolumn{2}{|c|}{0.16} & \multicolumn{2}{|c|}{0.06} \\
\hline
\end{tabular}

***p $<.01$.

significant at the $1 \%$ level. The final model also leaves the same control variable (AGE) remaining significant in the model, with a negative beta of -0.12 , and falling in significance to the $5 \%$ level $(\beta=-0.12, t=-2.55, p<.05)$. Thus, in the final model, younger firms tend to perform better in the sample with both variables.

\section{Hierarchical regression results - non-family firms}

Model 1 in the non-family sample was similarly regressed on one control variable, AGE, against PERF. Model 2 includes the same two control variables (AGE and SIZE), and once again no significance exists. Model 3 introduces the first independent variable KNOW with AGE and SIZE. Again, the analysis shows significance for the knowledge variable but with less strength and explanation of performance. Knowledge has a strong result $(\beta=0.41, t=5.14, p<.01)$. The $t$ value is significant at the $1 \%$ level at 5.14 , but Model 3 shows that the adjusted $R^{2}$ is 0.16 , thus explaining only $16 \%$ of the variance. ANOVA $F$ is very significant at the $1 \%$ level but again less substantial compared to family firms ( 9.80 and 43.56, respectively). Thus, the independent variable knowledge is making a contribution in the explanation of performance but a weaker contribution as compared to family firms as described in Table 5 . The control variable AGE is not significant in Model 3.

In Model 4, the introduction of the variable INN is completed $(\beta=0.40, t=3.35, p<$ .01 ). The adjusted $R^{2}$ improves to 0.22 , with only a slight increase in the $F$ value (from 9.80 to 10.72), but is still significant at the $1 \%$ level. Compared to Model 3, there remains a significant $t$ value for innovation - but not for the knowledge variable, which is no longer significant in the final model.

\section{Results from hypothesis testing}

Hypothesis 1 states that firm performance is positively related to innovation in family firms. The hypothesis is supported for the family sample and also supported in the non-family sample. The family firm's $R^{2}$ explains $44 \%$ of the variance and is significant at the $1 \%$ level. The non-family sample indicates that the $R^{2}$ explains $22 \%$ of the variance and is still significant at the $1 \%$ level. These results suggest that evidence exists on the importance of innovation in both family and non-family firms. However, the 
results are stronger for family firms. Therefore, we conclude that hypothesis 1 is partially supported.

Hypothesis 2 states that firm performance is positively related to knowledge and innovation as compared to non-family firms. The hypothesis is supported. The family sample findings are significant at the $1 \%$ level for the independent variables knowledge ( $\beta=0.24, t=4.02)$ and innovation $(\beta=0.44, t=7.28)$ with $44 \%$ of the variance explained. However, the non-family sample indicates no significance for the knowledge variable ( $\beta=0.11, t=0.88$ ). These results indicate that there is evidence for support for innovation and knowledge in family firms. Therefore, hypothesis 2 is supported.

\section{Discussion and conclusion}

The results showed strong support for innovation in both family and non-family firms. This research supports recent research by Kellermanns et al. (2010) and Naldi et al. (2007) which found a positive relationship between innovativeness and family firm performance. More specifically, knowledge was identified as a key variable with innovation in family organizations. It is concluded that innovation and knowledge resources have the strongest influence on family firm performance.

The effect of innovation was the strongest overall performance indicator from the study. Based on this finding and from previous research, it appears safe to say that innovation contributes to improved firm performance in both family and non-family firms. SMEs should manage their business with regard to the development of new and existing products and services, proactiveness and calculated risk-taking, innovative marketing, and others as suggested by the innovation variable. Therefore, even though the development of an innovative company culture can be complex and a timeconsuming process, this may result in benefits to the firm. Policy-makers may need to afford a means of identifying the resources that include innovation and knowledge as this may affect the performance of small family firms.

The findings in this study are perhaps most interesting with regard to knowledge. Family firms showed a result that is consistent with the literature, which argues that knowledge resources have perhaps the greatest ability of all resources to serve as a source of sustainable competitive advantage (see, for example, Gold et al. 2001). Knowledge permits a firm to predict more accurately the nature and commercial potential of changes in the environment and the appropriateness of strategic and tactical actions (Cohen and Levinthal 1990). Thus, a firm is more capable of discovering and exploiting new opportunities (Shane 2000). For this study, knowledge was not only significant in the final model, but it also enhanced the explanation of the variance substantially compared to non-family firms.

The enhancement of knowledge emphasizes the gathering of new knowledge, which can often be achieved through employees, by encouraging them to sustain their application, distribution, and creation of knowledge (Hauschild et al. 2001). Firms should be continually encouraging family and non-family members to update existing knowledge to develop new competencies that will be beneficial (Lee and Sukoco 2007). Acquiring new knowledge is best accomplished if internal processes are established for individuals to interact and collaborate with each other and facilitate the transmission and dissemination of knowledge that can enhance firm performance (Leonard and Sensiper 1998), which is often found in family firms. 
The relationship between a family firm's knowledge-based resources and performance should influence the way a firm is organized to exploit these resources (Wiklund and Shepherd 2003). Similar to many emerging concepts, it is acknowledged that the constructs and theory surrounding knowledge in terms of its content, use, and role within an organization are often complex (Skilton 2009). While this research has approached the analysis from the perspective of an organization, it can be studied from its content or from individuals. The processes of knowledge acquisition, conversion, and application form a perspective for a framework of knowledge integration within an organization (Gold et al. 2001).

Knowledge resources are known to be critical for firms for two main reasons. First, knowledge resources lay an early foundation for competitive advantage as the founding family or entrepreneur/team possess only their initial ideas about the opportunity. Through a variety of activities, including searches of networks (Dubini and Aldrich 1991), the idea can be further investigated and refined. Synthesizing this information aids in revealing the overall potential of the opportunity and provides the basis for a strategic foundation from which to build the venture (West and Noel 2009). The synthesizing of information is ultimately distinctive for each venture and exhibits the characteristics of resource-based theory as being valuable, rare, inimitable, and nonsubstitutable (Barney 1991).

Second, knowledge resources can lead to the development of other important resources (Gilbert et al. 2008). The sharing of information and understanding about opportunities enable firms to attract other human capital, financial investment, or technological capabilities (Zahra et al. 2007). Brush et al. (2001) found that complex, intangible knowledge resources possessed by the founders were key to acquiring other resources. Recent research showing support for knowledge resources are supported by West and Noel (2009), who found that knowledge resources generated by individuals can be used to enhance firm performance. These findings point to knowledge providing a foundation for other resource bundles to be accumulated and developed by the firm and help explain the significant results in family firms.

There was a surprising lack of support for knowledge resources in non-family firms. Non-family results from Model 3 ( $\beta=0.11, t=0.88$, and $22 \%$ of the variance explained) are in contrast to the previous discussion regarding the importance of knowledge resources and knowledge management. In the context of the current research, this finding may be partially explained due to tacit knowledge necessary for advantages in family firms. That is, the unique effect of the family firm on performance and the specific interaction of innovation must be considered together with other factors to fully understand family firm performance.

Research has suggested that persistence with a certain focus (or strategy) can be detrimental (Audia et al. 2000). Tzabbar et al. (2008) suggested that the underlying theories suggesting that more knowledge is always better may not be correct. They argue that boundaries exist for knowledge resources and that the effectiveness of the knowledge is limited to the degree of complementarities with other types of learning as often found with family firms. The result for non-family firms may reflect this reasoning.

The regression testing in the final model showed that firm age had some influence on the relationships for family firms with regard to knowledge and innovation $(\beta=-0.12$, $t=-2.55, p<.05)$. This negative result indicates that older firms have lower 
performance, everything else constant. This finding could indicate that as firms become less innovative as they age, they become more bureaucratic over time with increases in size and scope, for example, an increasing reliance on specific customers, suppliers, or markets.

The theoretical implications of this research strongly support the notion that family firms possess a predisposition for innovation and the successful management of knowledge resources. The relationship between family firms' innovation and performance should consider knowledge-based capabilities and the processes involved with the acquisition and management of this resource, and influence the way a firm is organized to exploit knowledge. Thus, a close link between innovation and knowledge exists. Innovation has emerged over the last several years as a dominant perspective in entrepreneurship research, and this research has aligned with prior recent research that this concept indeed has potential to explain performance in smaller family-owned organizations (Lichtenthaler and Muethel 2012).

Innovative features are often firm-specific, and difficult and time-consuming to imitate, making them potential sources of competitive advantage (Dierickx and Cool 1989). Managers in smaller companies should attempt to incorporate this innovative orientation into strategic planning and decision-making. As family firms are often managed by key family member executives, often only a few are involved in the decisionmaking process. Therefore, the influence of innovation should resonate within the CEO or team members in order to affect the firm performance.

Managers are challenged to provide an organizational culture that encourages employees to actively participate in learning and effective knowledge sharing. Importantly, knowledge resources are socially complex and are difficult to be imitated by competitors (Chuang 2004). The accumulation of knowledge is important early in the life cycle of firms as it can establish sustainability through its characteristics (West and Noel 2009), and therefore, knowledge may have implications for long-term growth. For example, research suggests linkages between education and economic development and in general concludes that the more educated the citizens the more entrepreneurial they tend to be and thus more rapid economic growth (Florida 2002). Further, knowledge has been tied to the development in the number of SMEs in economies (Petrakis and Kostis 2012).

Through establishing a link between knowledge, innovation, and firm performance, this research serves to inform managers that firms need to be effectively managed for overall knowledge management capability. Effective management of knowledge resources involves the focus on processes that involve a variety of different aspects, from the acquisition of new knowledge to the application of that knowledge. Government and other support institutions should consider establishing training programs for improving managerial knowledge and competency in strategic planning. While this research may not be able to address all potential obstacles that managers face in their quest to create successful high-growth firms, it does imply that certain firms may be predisposed to successful knowledge integration. Specifically, firms that exhibit expertise along the dimensions of process elements (acquisition, transformation, and conversion of knowledge) will tend to experience higher levels of performance.

Limitations include drawing from a convenience sample across multiple industries, which may prove problematic for generalizability. However, on the basis of testing 
discussed in the 'Sample' subsection of the 'Methods' section, we are confident in the validity and reliability of the sample. The cross-sectional nature of the data collection limits potential findings, and it is unclear if similar results would be found in a comparison of large companies. As innovation and knowledge resources and capabilities are accumulated and managed over time, a longitudinal approach would provide more reliable data. While this research combined two samples from different countries, evidence of how this process can enhance the study was presented. The current study utilized the variable 'performance' as a subjective measure, as opposed to other more common measures such as profitability or sales. Thus, results should be considered within these limitations. This study revealed insight between variables and that they may be hierarchical, but further examination through path analysis would help in exploring relationships in more detail.

As discussed previously, combining the two samples in Australia and the USA is acceptable with reference to Hofstede's dimensions of culture (Hofstede 1991; Reynolds et al. 2004), and statistical testing showed that there is little to be determined from separating the two samples in the results of this study. Support of these variables in both sets of data in this study is consistent with prior research, suggesting that the direct impact of national culture on variables is not evident as entrepreneurs share similar sets of values regardless of culture (McGrath et al. 1992).

Western nations have long benefited from a stable infrastructure, steady supply of capital, and abundance of skilled labor and technology (Ebert and Griffin 2005; Jorgenson 2001). Such conditions aided in the establishment of economic systems supportive of innovative capacity and knowledge-based competencies, which are a dominant driver of wealth creation and employment (Lee and Peterson 2000). Similarly, many Western nations such as some European countries, Japan, Australia, and New Zealand have factored consistently in recent entrepreneurship studies as being conducive to entrepreneurship (Busenitz et al. 2000; Autio 2005). Thus, the question of whether the findings are specific to Australia and the USA (or Western countries in general) or perhaps more universal is debateable.

Future research opportunities may exist to understand the role of innovation at varying points in time during the evolution of family firms. Do the dimensions of the innovation scale become less important for example? Additionally, consideration of variables that can affect the innovation-performance relationship could be an important area for research in the family firm field. Future research could benefit from a closer examination of the findings with regard to knowledge and innovation in family firms, for example, as a moderator/mediator relationship. Managing knowledge resources within an organization requires several elements. These have been described as acquisition-oriented processes, conversion-oriented processes, and application-oriented processes (Gold et al. 2001). The notion of how knowledge is acquired and how it is assembled and restructured can provide a competitive advantage for a company (Lee et al. 2005) and may provide an interesting future study. Finally, objective performance measures may yield different results with performance data that could be independently verified.

Though recent research on family firms has begun to yield findings about performance in family firms, the application of innovation and knowledge in the realm of small firms provides a refined view of the conditions necessary that can lead to superior performance in family SMEs. This research argues that innovation and knowledge 
resources are the most critical for family SMEs. The empirical study examines 430 firms and contributes to our knowledge about performance in SMEs in both family and nonfamily firms. While the firms have differing industry backgrounds, research conducted by Crook et al. (2008) showed no significant differences across small and large firms or service versus manufacturing firms. Small businesses do however face enormous challenges, and policy-makers will need to address issues presented in this research and elsewhere to maintain and develop a strong economic presence. These include factors such as encouraging a strong innovation culture and the development of knowledge resources. As core elements in the findings of this research, these concepts are essential, both individually and collectively, for the creation of more successful family businesses.

\section{Methods}

Currently, the SBA defines a business concern as one that is organized for profit; has a place of business in the USA; operates primarily within the USA; makes a significant contribution to the US economy through the payment of taxes or the use of American products, materials, or labor; is independently owned and operated; and is dominant in its field on a national basis. The business may be a sole proprietorship, partnership, corporation, or any other legal form. Size standards categorize small business in the USA that are determined through a set of guidelines administered by the SBA and vary according to industry. Generally, 'small' in the USA is considered to be fewer than 100 employees, and medium-sized is under 500 employees (Headd and Saade 2008).

\section{Sample}

The population of interest in this study was family and non-family SMEs, with 430 useable surveys returned. The majority of the responses were received electronically and the remainder personally delivered to random businesses that fit the SME criteria. This study utilized combined samples from Australia and the USA and was done for two main reasons: First, research suggests that Australian and US societies share many of the same characteristics: economically, socially, politically, etc., and most Western societies hold similar individualist cultural values (Hofstede 1991). Thus, responses are not expected to differ greatly between samples.

Second, from a methodological perspective, by combining and aggregating the two samples, greater stability can be achieved through an increase in the sample size. The benefits of an increased sample size outweigh the disadvantages, through developing a more reliable sampling group by combining the two subgroups. Research suggests that this method can be appropriate when the research design is consistent by ensuring constant definitions, measurements, models, and variables (Kish 1994). This process, or a 'multipopulation design', allows a combination of samples, and is indeed very efficient, if the sample design and allocation are adhered to (Kish 1994, p. 168). While the firms have differing industry backgrounds, research conducted by Crook et al. (2008) showed no significant differences across small and large firms or service versus manufacturing firms. This suggests that performance and resources such as knowledge and innovation are important across a range of contexts (Crook et al. 2008).

However, due to the convenience sampling procedure implemented in this research, further testing was conducted to enhance generalizability. First, a chi-square test 
showed no significant difference between the US and Australian samples. Second, a regression analysis with each sample was conducted to investigate whether the two samples varied from the findings of the combined data sets in terms of nationality and industry. In order to test for country effects, the data were broken into two subsets: (1) US family and non-family respondents and (2) Australian family and nonfamily respondents. In addition, the sample was also tested for field effects due to the sample being derived from various industries. Findings confirm that in all cases the country effect and field effects of industry have no significantly different effect on the results when compared to the combined samples. The results of these regression analyses follow.

First, hierarchical regression analysis conducted on the US sample indicated no significance for the control variables age and firm size for family and non-family samples. The same result was found in the Australian sample. Second, the first independent variable introduced in the model, 'knowledge', had a significant result in both samples. In the US family sample, the adjusted $R^{2}$ is 0.39 and significant at the $1 \%$ level ( $\beta=$ $0.61, t=10.52, p<.01$ ) and is mirrored in the non-family sample. The Australian data had less explanation in the family sample, and the adjusted $R^{2}$ was 0.15 but significant at the $1 \%$ level $(\beta=0.39, t=4.42, p<.01)$.

As described earlier, parallel testing was conducted for all non-family samples with comparable results for each data set. For example, the hierarchical model with the innovation variable in the US family data set explained $42 \%$ of the variance and was significant at the $1 \%$ level $(\beta=2.91, t=3.09, p<.01)$. Again, this was concurrent with the Australian findings $\left(R^{2}=0.42, \beta=0.69, t=7.03, p<.01\right)$. Non-family results also followed this pattern.

Similar tests were conducted for the innovation variable in both subsets with results echoing the final results. That is, innovation had an increased presence in the final model overshadowing knowledge resources. In the US sample, the adjusted $R^{2}$ is 0.39 and significant at the $1 \%$ level $(\beta=0.61, t=10.52, p<.01)$. In the Australian sample, the adjusted $R^{2}$ is 0.15 and significant at the $1 \%$ level $(\beta=0.39, t=4.42, p<.01)$.

As the data were collected from various industries, they were tested in further regression analysis for possible industry effects. Initial hierarchical regression testing following the same procedure utilizing age and firm size as control variables and introducing knowledge and innovation variables utilizing different industries such as retail and nonretail was analyzed. Once again, similar results were obtained with retail and non-retail industries showing no significance with the control variables. Once again, significance was demonstrated with the knowledge variable being introduced, for example, in retail $(\beta=0.51, t=9.70, p<.01)$ and the full model having an adjusted $R^{2}=0.27$. When the innovation variable is introduced, again, similar previous results were found: retail adjusted $R^{2}=0.44(\beta=0.61, t=6.41, p<.01)$ and non-retail adjusted $R^{2}=0.34(\beta=0.48$, $t=6.0, p<.01)$.

Finally, there remains the widespread use of convenience sampling in both entrepreneurship and family research. For example, a meta-analysis of the family research field by Bird et al. (2004) found that $66 \%$ of all articles used convenience sampling. Thus, it was considered appropriate to combine both Australian and US samples for the final regression analyses. In total, 430 useable responses were received, and family firms numbered 293 and non-family consisted of 137 companies. 


\section{Personal/mail survey}

The survey with a covering letter was dispersed in Australia and the USA via email and in person. Two versions of the survey instrument: mail and online, were administered. The online survey was administered through three emails. The personal delivery method is acknowledged to increase response rates as completed responses can help (a) establish rapport with respondents while introducing the survey, (b) provide clarifications if needed quickly, and (c) collect the questionnaire immediately (Cavana et al. 2001). Furthermore, personal contact and networks can be utilized to find appropriate additional participants following the snowball sampling method described by Neuman (2003).

\section{Scale development Innovation}

Early research has examined the important role of innovation within entrepreneurship (Schumpeter 1947). Therefore, in order to measure innovation, several dimensions were included in a 12-item, seven-point Likert scale. First, new product development is an area that demonstrates where companies have exhibited innovative capability, and we have developed four items that include (1) the number of new products developed and (2) the emphasis of product development and innovation within the firm. In addition, existing unique products/services in the company's portfolio are investigated. In order for innovation to occur, entrepreneurs should be forward thinking and exhibit opportunity recognition and exploitation skills, three items that measured the willingness of firms to take on new opportunities and also their willingness to adjust their business as necessary in order to exploit them. The proactive nature of firms to utilize opportunities was measured by action and decisionmaking shown in uncertain situations.

Innovation throughout an organization was also examined with regard to general business practices, such as whether firms search for new practices, are among the first to implement innovative processes and practices, and allocate resources to new and promising areas. The importance of innovative marketing practices has been recognized by several scholars (Hills et al. 2007; O'Dwyer et al. 2009). Creativity has been acknowledged as a possible key to innovative capacity; therefore, overall firm creativity and innovation in accomplishing company goals was included.

Most items in the innovation scale were sourced from questions in existing scales from the entrepreneurship, SME, and strategy literature (for example, Covin and Slevin 1989; Edelman et al. 2005; Gundry and Welsch 2001; Hitt and Ireland 2000; Lee and Sukoco 2007; Wiklund and Shepherd 2003). Pretests regarding the clarity of the survey were conducted with firms of varying sizes and belonging to different sectors, as well as academics. Based on their recommendations, final versions of both survey instruments were completed.

\section{Knowledge}

Knowledge is described as the continuous process of managing all knowledge in order to anticipate current and future needs, to identify and exploit existing and acquired knowledge, as well as to develop new opportunities (Carrillo et al. 2004; Quintas et al. 1997). Following Alavi and Leidner (2001), the knowledge variable is described as a knowledge management process, which involves creating, storing/retrieving, transferring, and applying 
knowledge. The creation process refers to the organizations' effort to gather information and new knowledge from internal and external sources and then codify it into explicit knowledge. The codification process is then followed by the storing process which enables fast retrieval in order to develop new knowledge for later use.

\section{Performance}

Frequently used measures of performance criteria include profitability, ROI, number of employees, and revenues. Each measure has strengths and weaknesses (Brush and Wanderwerf 1992; McGee et al. 1995). The acknowledged differences between industries in the sample require that characteristics of the industry in which the venture operates be taken into consideration when measuring performance (Sandberg and Hofer 1987). Therefore, subjective performance measures were utilized indicating the perceptions on performance goals with regard to sales and growth compared to competitors and an overall evaluation of performance. This follows the typology of strategy of Miles and Snow (1978) to investigate the degree to which firms engage in strategies to grow and expand.

Two control variables were added to the final model: firm size and age. Firm size was measured using the number of employees and firm age using years in business. The scales were subjected to reliability and validity testing, and factor analysis was used to reduce the number of items in some scales. Hierarchical linear regression analysis was utilized to analyze the relationships between the variables in the final model.

\section{Competing interests}

The authors declare that they have no competing interests.

\section{Authors' contributions}

DP conceived the study, gathered the data, and drafted the manuscript. MS contributed to the research design and performed the statistical analysis. RJB contributed to the data analysis, coordination, and final editing. All authors have read and approved the final manuscript.

Received: 28 March 2013 Accepted: 31 May 2013

Published: 15 June 2013

\section{References}

Achtenhagen, L, Naldi, L, \& Melin, L. (2010). "Business growth" - do practitioners and scholars really talk about the same thing? Entrepreneurship Theory and Practice, 34, 289-316.

Alavi, M, \& Leidner, D. (2001). Knowledge management and knowledge management systems: conceptual foundations and research issues. MIS Quarterly, 25(1), 107-136.

Allio, M. (2004). Family businesses: their virtues, vices and strategic path. Strategy and Leadership, 32, 24-34.

Allocca, MA, \& Kessler, EH. (2006). Innovation speed in small and medium-sized enterprises. Creativity and Innovation Management, 15(3), 279-295.

Amabile, TM. (1996). Creativity in context: update to the social psychology of creativity. Boulder: Westview.

Anderson, BS, \& Eshima, Y. (2011). The influence of firm age and intangible resources on the relationship between entrepreneurial orientation and firm growth among Japanese SMEs. Journal of Business Venturing. doi:10.1016/j.jbusvent.2011.10.001.

Anderson, R, \& Reeb, D. (2003). Founding-family ownership and firm performance: evidence from S\&P 500. Journal of Finance, 58, 1301-1327.

Andres, C. (2008). Large shareholders and firm performance-an empirical examination of founding-family ownership. Journal of Corporate Finance, 14, 431-445.

Astrachan, JH, \& Shanker, MC. (2003). "Family businesses" contribution to the U.S. economy: a closer look. Family Business Review, 16(3), 211-219

Astrachan, JH, Zahra, SA, \& Sharma, P. (2003). Family-sponsored ventures. Paper presented at the first annual global entrepreneurship symposium, New York, 29 Apr 2003.

Audia, P, Locke, E, \& Smith, K. (2000). The paradox of success: an archival and a laboratory study of strategic persistence following a radical environmental change. The Academy of Management Journal, 43, 837-853.

Autio, E. (2005). Global entrepreneurship monitor. Report on high-expectation entrepreneurship. Wellesley: London Business School/Mazars/Babson.

Barney, J. (1991). Firm resources and sustained competitive advantage. Journal of Management, 17, 99-120.

Bird, B, Welsch, H, Astrachan, JH, \& Pistrui, D. (2004). Family business research: the evolution of an academic field. Family Business Review, 15(4), 337-350.

Block, JH. (2012). R\&D investments and family firms: an agency perspective. Journal of Business Venturing, 27, 248-275. 
Bruderl, J, \& Preisendorfer, P. (2000). Fast growing businesses: empirical evidence from a German study. International Journal of Sociology, 30, 45-70.

Brush, CG, Greene, PG, \& Hart, MM. (2001). From initial idea to unique advantage: the entrepreneurial challenge of constructing a resource base. Academy of Management Executive, 15(1), 64-80.

Brush, CG, \& Wanderwerf, PA. (1992). A comparison of methods and sources for obtaining estimates of new venture performance. Journal of Business Venturing, 7, 157-170.

Burkart, M, Panunzi, F, \& Shleifer, A. (2003). Family firms. Journal of Finance, 58(5), 2167-201.

Busenitz, LW, Gomez, C, \& Spencer, JW. (2000). Country institutional profiles: unlocking entrepreneurial phenomena. The Academy of Management Journal, 43(5), 994-1003.

Carney, M. (2005). Corporate governance and competitive advantage in family-controlled firms. Entrepreneurship Theory and Practice, 29, 249-266.

Carrillo, P, Robinson, HI, AlgGhassani, A, \& Anumba, C. (2004). Knowledge management in UK construction: strategies, resources and barriers. Project Management Journal, 35(1), 46.

Cavana, RY, Delahaye, BL, \& Sekaran, U. (2001). Applied business research: qualitative and quantitative methods. Milton: Wiley.

Chrisman, JJ, Chua, JH, \& Sharma, P. (2005). Trends and directions in the development of a strategic management theory of the family firm. Entrepreneurship Theory and Practice, 29, 555-575.

Chrisman, JJ, Kellermanns, FW, Chan, KC, \& Liano, K. (2010). Intellectual foundations of current research in family business: an identification and review of 25 influential articles. Family Business Review, 23(1), 9-26.

Christenson, C. (1997). The innovator's dilemma. Cambridge: Harvard Business School Press.

Chuang, S-H. (2004). A resource-based perspective on knowledge management capability and competitive advantage: an empirical investigation. Expert Systems with Applications, 27, 459-465.

Cohen, WM, \& Levinthal, DA. (1990). Absorptive capacity: a new perspective on learning and innovation. Administrative Science Quarterly, 35, 128-152.

Covin, J, \& Slevin, D. (1989). Strategic management of small firms in hostile and benign environments. Strategic Management Journal, 10(1), 75-87.

Crook, TR, Ketchen, DJ, Jr, Combs, JG, \& Todd, SY. (2008). Strategic resources and performance: a meta-analysis. Strategic Management Journal, 29, 1141-1154.

De Massis, A, Sharma, PA, Chua, JH, \& Chrisman, JJ. (2012). Family business studies: an annotated bibliography. Northampton: Edward Elgar.

Dess, GG, Pinkham, BC, \& Yang, H. (2011). Entrepreneurial orientation: assessing the construct's validity and addressing some of its implications for research in the areas of family business and organizational learning. Entrepreneurship Theory and Practice, 35(5), 1077-1090.

Dierickx, I, \& Cool, K. (1989). Asset stock accumulation and sustainability of competitive advantage. Management Science, 35, 1504-1511.

Dubini, P, \& Aldrich, H. (1991). Personal and extended networks are central to the entrepreneurial process. Journal of Business Venturing, 10, 305-313.

Ebert, RJ, \& Griffin, RW. (2005). Business essentials. Upper Saddle River: Prentice Hall.

Eddleston, KA, \& Kellermanns, FW. (2007). Destructive and productive family relationships: a stewardship theory perspective. Journal of Business Venturing, 22(4), 545-565.

Eddleston, KA, Kellermanns, FW, \& Sarathy, R. (2008). Resource configuration in family firms: linking resources, strategic planning and technological opportunities to performance. Journal of Management Studies, 45, 26-50.

Edelman, LF, Brush, CG, \& Manolova, T. (2005). Co-alignment in the resource-performance relationship: strategy as a mediator. Journal of Business Venturing, 20, 359-383.

Florida, R. (2002). The rise of the creative class: and how it's transforming work, leisure, community and everyday life. New York: Basic Books.

Gedajlovic, E, \& Carney, M. (2010). Markets, hierarchies, and families: toward a transaction cost theory of the family firm. Entrepreneurship Theory and Practice, 34, 1145-1172.

Gilbert, BA, McDougall, PP, \& Audretsch, DB. (2008). Clusters, knowledge spillovers and new venture performance: an empirical examination. Journal of Business Venturing, 23(4), 405-422.

Glynn, MA. (1996). Innovative genius: a framework for relating individual and organizational intelligences to innovation. The Academy of Management Review, 21, 1081-1111.

Gold, AH, Malhotra, A, \& Segars, AH. (2001). Knowledge management: an organizational capabilities perspective. Journal of Management Information Systems, 18, 185-214.

Grant, RM. (1996). Toward a knowledge-based theory of the firm. Strategic Management Journal, 17, 109-122.

Greenwood, R, \& Miller, D. (2010). Tackling design anew: getting back to the heart of organizational theory. Academy of Management Perspectives, 24, 78-88.

Gudmunson, D, Tower, CB, \& Hartman, FA. (2003). Innovation in small business: culture and ownership structure do matter. Journal of Developmental Entrepreneurship, 8, 1-17.

Gundry, HP, \& Welsch, LK. (2001). The ambitious entrepreneur: high growth strategies of women-owned enterprises. Journal of Business Venturing, 16, 453-470.

Hambrick, DC, \& D'Aveni, RA. (1988). Large corporate failures as downward spirals. Administrative Science Quarterly, 33, 1-23. Harrison, LE, \& Huntington, SP. (2000). Culture matters: how values shape human progress. New York: Basic Books. Hauschild, S, Licht, T, \& Stein, W. (2001). Creating a knowledge culture. The McKinsey Quarterly, 1, 74-81.

Headd, B, \& Saade, R. (2008). Do business definition decisions distort small business research results? Washington, D.C.: Office of Advocacy of the U.S. Small Business Administration.

Heck, RKZ, \& Trent, E. (1999). The prevalence of family business from a household sample. Family Business Review, 12, 209-224.

Helfat, CC. (1994). Firm specifity in corporate applied R\&D. Organization Science, 5(2), 173-184.

Hills, GE, Hultman, CM, \& Miles, MP. (2007). The evolution and development of entrepreneurial marketing. Journal of Small Business Management, 46(1), 99-112.

Hitt, MA, \& Ireland, RD. (2000). The intersection of entrepreneurship and strategic management research. In DL Sexton \& H Landstrom (Eds.), The Blackwell handbook of entrepreneurship (pp. 45-63). Oxford: Blackwell. 
Hofstede, G. (1991). Cultures and organizations: software of the mind. London: McGraw-Hill.

Holt, DT, Rutherford, MW, \& Kuratko, DF. (2010). Advancing the field of family business research: further testing the measurement properties of the F-PEC. Family Business Review, 23(1), 76-88.

Jorgenson, DW. (2001). Information technology and the U.S. economy. The American Economic Review, 91(1), 1-32.

Katz, N, \& Du Preez, N. (2008). The role of knowledge management in supporting a radical innovation project. In A Bernard \& S Tichkiewitch (Eds.), Methods and tools for effective knowledge life-cycle management (pp. 331-346). Amsterdam: Springer.

Kaya, N, \& Patton, J. (2011). The effects of knowledge-based resources, market orientation and learning orientation on innovation performance: an empirical study of Turkish firms. Journal of International Development, 23, 204-219.

Kellermanns, FW, Eddleston, KA, Barnett, T, \& Pearson, A. (2008). Family member characteristics and involvement: effect on entrepreneurial behavior in the family firm. Family Business Review, 21, 1-14.

Kellermanns, FW, Eddleston, KA, Sarathy, R, \& Murphy, F. (2010). Innovativeness in family firms: a family influence perspective. Small Business Economics, 38(1), 85-101.

Kirzner, I. (1979). Perception, opportunity, and profit. Chicago: University of Chicago Press.

Kish, L. (1994). Multipopulation survey designs. International Statistical Review, 62, 167-186.

Klein, SB. (2000). Family business in Germany: significance and structure. Family Business Review, 13(3), 157-181.

Laursen, K, \& Salter, A. (2006). Open for innovation: the role of openness in explaining innovation performance among UK manufacturing firms. Strategic Management Journal, 27(2), 131-150.

Le Breton-Miller, IL, \& Miller, D. (2006). Why do some family businesses out compete? Governance, long-term orientations, and sustainable capability. Entrepreneurship Theory and Practice, 30, 731-746.

Lee, KC, Lee, S, \& Kang, IW. (2005). KMPI: measuring knowledge management performance, information and management. Information Management, 42(3), 469-482.

Lee, SM, \& Peterson, SJ. (2000). Culture, entrepreneurial orientation and global competitiveness. Journal of World Business, 35(4), 401-416.

Lee, SM, \& Sukoco, BM. (2007). The effects of entrepreneurial orientation and knowledge management capability on organizational effectiveness in Taiwan: the moderating role of social capital. International Journal of Management, 24(3), 549-572.

Leonard, D, \& Sensiper, S. (1998). The role of tacit knowledge in group innovation. California Management Review, 40(3), 112-132.

Liao, J, Kickul, JR, \& Ma, H. (2009). Organizational dynamic capability and innovation: an empirical examination of internet firms. Journal of Small Business Management, 47(3), 263-286.

Lichtenthaler, U, \& Muethel, M. (2012). The impact of family involvement on dynamic innovation capabilities: evidence from German manufacturing firms. Entrepreneurship Theory and Practice. doi:10.1111/j.1540-6520.2012.00548.x.

Ling, Y, \& Kellermanns, FW. (2009). The effects of family firm specific sources of TMT diversity: the moderating role of information exchange frequency. Journal of Management Studies, 47(2), 322-344.

Lumpkin, GT, Brigham, KH, \& Moss, TW. (2010). Long-term orientation: implications for the entrepreneurial orientation and performance of family firms. Entrepreneurship \& Regional Development, 22(3), 1-24.

Lumpkin, GT, \& Dess, GG. (1996). Clarifying the entrepreneurial orientation construct and linking it to performance. The Academy of Management Review, 21(1), 35-172.

Martin, WL, \& Lumpkin, GT. (2003). From entrepreneurial orientation to "family orientation": generational differences in the management of family business. In WD Bygrave (Ed.), Frontiers of entrepreneurship research: proceedings of the $23^{\text {rd }}$ annual entrepreneurship research conference (pp. 309-321). Babson Park: Babson College.

McCann, JE, Leon-Guerrero, AY, \& Haley, JD. (2001). Strategic goals and practices of innovative family businesses. Journal of Small Business Management, 39, 50-59.

McConaugby, DL, Matthews, CH, \& Fialko, AS. (2001). Founding family controlled firms: performance, risk and value. Journal of Small Business Management, 39, 31-49.

McEvily, SK, \& Chakravarthy, B. (2002). The persistence of knowledge-based advantage: an empirical test for product performance and technological knowledge. Strategic Management Journal, 23(4), 285-305.

McGee, JE, Dowling, MJ, \& Megginson, WL. (1995). Cooperative strategy and new venture performance: the role of business strategy and management experience. Strategic Management Journal, 16(7), 565-580.

McGrath, RG. (2001). Exploratory learning, innovative capacity, and managerial oversight. The Academy of Management Journal, 44, 118-131.

McGrath, RG, McMillan, IC, \& Scheinberg, S. (1992). Elitists, risk-takers and rugged individualists? An exploratory analysis of cultural differences between entrepreneurs and non-entrepreneurs. Journal of Business Venturing, 7, 115-135.

Miles, R, \& Snow, C. (1978). Organizational strategy, structure and process. New York: McGraw-Hill.

Miller, DJ, Fern, MJ, \& Cardinal, LB. (2007). The use of knowledge for technological innovation within diversified firms. The Academy of Management Journal, 50(2), 308-326.

Miller, D, \& Le Breton-Miller, I. (2006). Family governance and firm performance: agency, stewardship, and capabilities. Family Business Review, 19, 73-87.

Miller, D, Le Breton-Miller, I, \& Lester, RH. (2011). Family and lone founder ownership and strategic behavior: social context, identity and institutional logics. Journal of Management Studies, 48(1), 2-25.

Miller, D, \& Shamsie, J. (1996). The resource-based view of the firm in two environments: the Hollywood film studios from 1936 to 1965. The Academy of Management Journal, 39, 519-543.

Moreno, AM, \& Casillas, JC. (2008). Entrepreneurial orientation and growth of SMEs: a causal model. Entrepreneurship: Theory and Practice, 32, 507-528.

Naldi, L, Nordqvist, M, Sjoberg, K, \& Wiklund, J. (2007). Entrepreneurial orientation, risk-taking, and performance in family firms. Family Business Review, 20(1), 33-47.

Neuman, WL. (2003). Social research methods: qualitative and quantitative approaches (5th ed.). Boston: Allyn \& Bacon.

Nonaka, I, Toyama, R, Konno, N, \& Seci, B. (2000). Leadership: a unified model of dynamic knowledge creation. Long Range Planning, 33, 5-34. 
Nooteboom, B. (1994). Innovation and diffusion in small firms: theory and evidence. Small Business Economics, 6(5), 327-347. Nordqvist, M. (2012). Understanding strategy processes in family firms: exploring the roles of actors and arenas. International Small Business Journal, 30(1), 24-40.

O'Boyle, E, Jr, Pollack, JM, \& Rutherford, MW. (2012). Exploring the relationship between family involvement and firms' finance performance: a meta-analysis of main and moderator effects. Journal of Business Venturing, 27, 1-18.

O'Dwyer, M, Gilmore, A, \& Carson, D. (2009). Innovative marketing in SMEs. European Journal of Marketing, 43(1/2), 46-61.

Pavitt, K. (1991). What makes basic research economically useful? Research Policy, 20(2), 109-119.

Peng, MW, \& Jiang, Y. (2010). Institutions behind family ownership and control in large firms. Journal of Management Studies, $47,253-273$.

Petrakis, PE, \& Kostis, PC. (2012). The role of knowledge and trust in SMEs. Journal of the Knowledge Economy, 1-20. doi:10.1007/s13132-012-0115-6.

Porter, ME. (1996). What is strategy? Harvard Business Review, 74(6), 61-78.

Quintas, P, Lefrere, P, \& Jones, G. (1997). Knowledge management: a strategic agenda. Long Range Planning, 30, 385-391.

Reynolds, PD, Bygrave, WD, Autio, E, Arenius, P, Fitzsimons, P, Minniti, M, Murray, S, O'Goran, C, \& Roche, F. (2004). Global Entrepreneurship Monitor (GEM) 2003 global report. Wellesley: Babson/London Business School/Kauffman Foundation.

Reynolds, PD, \& White, SB. (1997). The entrepreneurial process: economic growth, men, women, and minorities. Westport: Quorom Books.

Rigby, D, \& Zook, C. (2002). Open-market innovation. Harvard Business Review, 80(10), 80-89.

Ruef, M, Aldrich, HE, \& Carter, NM. (2002). Don't go to strangers: homophily, strong ties, and isolation in the formation of organizational founding teams. Chicago: American Sociological Association Meeting.

Rumelt, RP. (1984). Toward a strategic theory of the firm. In R Lamb (Ed.), Competitive strategic management (pp. 556-570). Englewood Cliffs: Prentice Hall.

Sandberg, WR, \& Hofer, CW. (1987). Improving new venture performance: the role of strategy, industry structure and the entrepreneur. Journal of Business Venturing, 2(1), 5-28.

Schumpeter, J. (1947). The creative response to economic history. Journal of Economic History, 7, 149-159.

Shane, S. (2000). Prior knowledge and the discovery of entrepreneurial opportunities. Organization Science, 11, 448-469.

Sharma, P. (2004). An overview of the field of family business studies: current status and directions for the future. Family Business Review, 17(1), 1-36.

Sharma, P, Chrisman, JJ, \& Gersick, KE. (2012). 25 years of family business review: reflections on the past and perspectives for the future. Family Business Review, 25, 5-15.

Short, JC, Payne, GT, Brigham, KH, Lumpkin, GT, \& Broberg, JC. (2009). Family business and entrepreneurial orientation in publicly traded businesses: a comparative analysis of the S\&P 500. Family Business Review, 22, 9-24.

Sirmon, DG, Arregle, J-L, Hitt, MA, \& Webb, JW. (2008). The role of family influence in strategic response to the threat of imitation. Entrepreneurship Theory and Practice, 32, 979-998.

Skilton, PF. (2009). Knowledge based resources, property based resources and supplier bargaining power in Hollywood motion picture projects. Journal of Business Venturing, 62, 834-840.

Skyrme, D, \& Arnindon, D. (1997). Creating the knowledge-based business. London: Business Intelligence.

Smith, WK, \& Lewis, MW. (2011). Toward a theory of paradox: a dynamic equilibrium model of organizing. The Academy of Management Review, 36, 381-403.

Spriggs, M, Yu, A, Deeds, D, \& Sorenson, RL. (2012). Too many cooks in the kitchen: innovative capacity, collaborative network orientation, and performance in small family businesses. Family Business Review. doi:10.1177/0894486512468600.

Steir, LP. (2009). Familial capitalism in global institutional contexts: implications for corporate governance and entrepreneurship in East Asia. Asia Pacific Journal of Management, 26, 513-535.

Teece, DJ, Pisano, G, \& Shuen, A. (1997). Dynamic capabilities and strategic management. Strategic Management Journal, 18(7), 509-533.

Tzabbar, D, Aharonson, BS, Ambugey, TL, \& Al-Laham, A. (2008). When is the whole bigger than the sum of its parts? Bundling knowledge stocks for innovative success. Strategic Organization, 6(4), 375-406.

Verhees, FJHM, \& Meulenberg, MTG. (2004). Market orientation, innovativeness, product innovation, and performance in small firms. Journal of Small Business Management, 42, 134-154.

Wang, HC, He, J, \& Mahoney, JT. (2009). Firm-specific knowledge resources and competitive advantage: the roles of economic- and relationship-based employee governance mechanisms. Strategic Management Journal, 30, 1265-1285.

West, GP, \& Noel, TW. (2009). The impact of knowledge resources on new venture performance. Journal of Small Business Management, 47(1), 1.

Wiklund, J, \& Shepherd, D. (2003). Knowledge-based resources, entrepreneurial orientation, and the performance of small and medium-sized businesses. Strategic Management Journal, 24, 1307-1314.

Wiklund, J, \& Shepherd, D. (2005). Entrepreneurial orientation and small business performance: a configurational approach. Journal of Business Venturing, 20(1), 71-91.

Wolff, JA, \& Pett, TL. (2006). Small-firm performance: modeling the role of product and process improvements. Journal of Small Business Management, 44(2), 268-284.

Zahra, SA. (2005). Entrepreneurial risk taking in family firms. Family Business Review, 18(1), 23-40.

Zahra, SA, Hayton, JC, \& Salvato, C. (2004). Entrepreneurship in family versus non-family firms: a resource-based analysis of the effect of organizational culture. Entrepreneurship Theory and Practice, 28(4), 363-381.

Zahra, SA, Neubaum, DO, \& Larraneta, B. (2007). Knowledge sharing and technological capabilities: the moderating role of family involvement. Journal of Business Research, 60, 1070-1079.

Zellweger, TM, \& Nason, RS. (2008). A stakeholder perspective on family firm performance. Family Business Review, 21, 203-216.

Zhou, KZ, \& Wu, F. (2010). Technology capability, strategic flexibility, and product innovation. Strategic Management Journal, 37(5), 547-561.

doi:10.1186/2192-5372-2-14

Cite this article as: Price et al: The relationship between innovation, knowledge, and performance in family and non-family firms: an analysis of SMEs. Journal of Innovation and Entrepreneurship 2013 2:14. 